\title{
Sürdürülebilir Rekabet Avantajı Sağlamada Kaynak Avantajı Teorisi ve Pazar Yönlülük Yaklaşımı
}

\author{
Mehmet MARANGOZ* Tuğçe Merve İNAK ÖZBERK**
}

\begin{abstract}
$\ddot{O} Z$
Günümüzde işletmeler mevcut rekabet koşullarında sürdürülebilir rekabet avantajını ellerinde bulundurmak için çeşitli stratejiler geliştirmektedir. Rekabet avantajını inceleyen işletmelerin kaynaklarını ve yetkinliklerini temel alan kaynak avantajı teorisi ilk kez Hunt ve Morgan (1995) tarafindan ortaya atılmıştır. Teorinin temel önermesi işletmelerin taklit edilemeyen, değerli, nadir kaynaklarının işletmelere rekabetçi avantaj sağlayarak, üstün finansal performans sağlamasıdır. Ayrıca, kaynak avantajı teorisine göre, pazar yönlülük bir işletmeye pazar bölümlerinin tercihlerine göre uygun ürünler üretmesine, proaktif olarak müsteri memnuniyetini sağlayıcı bilgiler sağladı̆̆ için işletmelerin bir tür kaynağı olarak ifade edilmektedir. Çalışmanın amacı, işletmelerde kaynak avantajı teorisi ve pazar yönlülüğün, sürdürülebilir rekabet avantajını elde etmelerindeki önemini değerlendirmek ve buna bağll olarak da öneriler getirilerek, literatüre katkl sağlamayı amaçlamaktadır. Sonuç olarak, kaynak avantajı teorisine göre talep, tüketici bilgisi, insan motivasyonu, işletme amacı ve bilgisi, kaynaklar, yönetimin rolü, rekabet dinamikleri gibi unsurların pazar yönlülük açısından da sürdürülebilir rekabet avantajı sağlamadaki önemi vurgulanmaktadır.
\end{abstract}

Anahtar Kelimeler: Sürdürülebilir rekabet avantajı, Kaynak avantajı teorisi, Pazar yönlülük, Kaynak avantajı teorisi ve işletmelere etkileri

JEL Sinıflandirılması: F10, M31, M10, D40

\section{Resource Advantage Theory and Market Orientation in Achieving a Sustainable Competitive Advantage}

\begin{abstract}
Today, businesses are developing various strategies to keep sustainable competitive advantage in the current competitive environment. Hunt and Morgan (1995) first introduced the resource advantage theory based on the resources and competencies of the enterprises that examined the competitive advantage. The basic proposition of the theory is that it provides superior financial performance by providing a competitive advantage to enterprises that cannot be imitated, valuable and rare. In addition, according to the theory of resource advantage, market orientation is expressed as a source of the enterprises because it provides proactive customer satisfaction information by producing an appropriate product according to the preferences of the market segments. The aim of the study is to evaluate the importance of resource advantage theory and market orientation in enterprises to achieve sustainable competitive advantage and to make suggestions to the literatüre. As a result, the importance of supply, consumer knowledge, human motivation, business purpose and knowledge, resources, the role of management, competitive dynamics, and the importance of providing sustainable competitive advantage in market direction are emphasized.
\end{abstract}

\footnotetext{
*Prof. Dr., Muğla Sitkı Koçman Üniversitesi, İktisadi ve İdari Bilimler Fakültesi, İşletme Bölümü, email: mehmetmarangoz @mu.edu.tr, ORCID bilgisi: 0000-0002-1589-2940

** Öğr. Gör., Muğla Sıtkı Koçman Üniversitesi, Datça Kazım Yılmaz Meslek Yüksekokulu, Ulaştırma Hizmetleri Bölümü, tugceinak@mu.edu.tr, ORCID bilgisi: 0000-0002-7642-346X
}

(Makale Gönderim Tarihi:13.03.2019 / Yayına Kabul Tarihi:12.03.2020)

Doi Number: 10.18657/yonveek.539379

Makale Türü: Araştırma Makalesi 
Mehmet Marangoz \& Tuğçe Merve Inak Özberk/Sürdürülebilir Rekabet Avantajı Sağlamada Kaynak Avantajı Teorisi ve Pazar Yönlülük Yaklaşımı

Key Words: Sustainable competitive advantage, Resource advantage theory, Market orientation, Resource advantage theory and its effects on enterprises

JEL Classification: F10, M31, M10, D40

\section{Gİiș}

Küresel rekabet ortamında sürdürülebilir rekabet avantajı sağlamayı hedefleyen işletmeler, bünyelerinde bulundurdukları temel yetenek ve kaynakları doğrultusunda güçlü- zayıf yanlarını ve sektör içerisinde firsat- tehditleri tespit ederek, doğru pazarlama stratejileriyle piyasada var olma çabası içerisindedirler.

Porter (1985)'e göre rekabet üstünlüğü, bir işletmenin rakiplerine kıyasla müşterilerine daha düşük maliyet veya farklı ürün ya da hizmet sunmasıyla ortaya çıkan konumsal üstünlük olarak tanımlanmaktadır. Kolayca kopyalanamaz olan bu sürdürülebilir rekabet üstünlügünü firmaların ancak; üstünlügün kaynağı, üstünlük kaynaklarının miktarı ve sürekli yenilik, iyileştirme politikaları koşullarını sağlayarak gerçekleştirmeleriyle mümkündür (Güleş ve Özilhan, 2010: 479). Bu bağlamda, artan rekabet ortamı işletmelere sürdürülebilir rekabet avantajı sağlayacak yol ve yöntemleri bulmaya zorlamaktadır.

Günümüzde işletmelere rekabet avantaj1 yaratan benzersiz kaynaklar işletmelerin temel yeteneklerini oluşturmaktadır (Doğanay ve Kırçova, 2016: 31). Morgan ve Hunt (1995) tarafindan ortaya atılan kaynak avantajı teorisinin de odak noktasi; temel yeteneklerin ve kaynakların tanımlanması ve bu doğrultuda işletmelerin piyasada rekabetçi üstünlük elde etmesini sağlamak olarak ifade edilmektedir (Hunt, 2015: 359).

İşletmelerin sürdürülebilir rekabet avantajına sahip olabilmesi için geçmişten günümüze geliştirilebilecek pazarlama stratejileri içerisinde kaynak temelli yaklaşım ve pazar yönlü yaklaşımın olduğunu görmek mümkündür (Hooley vd., 1998: 97). Kaynak temelli yaklaşıma göre rekabet avantajı sağlamanın işletmenin kaynaklarına ve yeteneklerine bağlı olduğu görüşü hakimdir (Koçak vd., 2005: 180). Bununla beraber, pazar yönlülük yaklaşımının ise; işletmelerin sürdürülebilir rekabet avantajı sağlayabilmesi için pazardaki mevcut ve potansiyel müşteri ihtiyaçlarının tespit edilmesi ve elde edilen verilerin tüm işletme fonksiyonları içerisinde paylaşılarak, ihtiyaçların rakiplere kıyasla daha etkin ve verimli bir şekilde karşılanması olarak ifade edilmektedir. Her iki yaklaşımdan oluşan sentezin, işletmelerin sürdürülebilir rekabet avantajı kazanmaları açısından oldukça önemli bir etki yaratacağını söylemek mümkündür.

Literatürde kaynak avantajı teorisi ile ilgili çalışmaların (Hunt ve Lambe, 2000; Koçak vd. 2005; Güleş ve Özilhan, 2010; Bicen ve Hunt, 2012; Doğanay ve Kırcova (2016) yanı sıra pazar yönlülük ile ilgili çalışmalar da (Karahan ve Özçiftçi, 2008; Marangoz ve Aydın, 2012; Durukan ve Hamşığlu, 2015; Hamşıŏlu, 2018) mevcuttur. Çalışmaların içeriği incelendiğinde, bu çalışmaların hem kavramsal hem de uygulamalı çalışmalar olduğu görülmektedir. Bununla birlikte, bu iki konuyu sürdürülebilir rekabet avantajı sağlama açısından irdeleyen ve inceleyen çalışma sayısının da (Kocak vd. 2005; Biçen ve Hunt, 2012) sınırlı olması nedeniyle ilgili konuların belirli sınırlıklar içerisinde ele alındığ 1 görülmektedir. Bu yönüyle bu çalışmanın, her iki kavramı (kaynak avantajı teorisi 
ve pazar yönlülük) sürdürülebilir rekabet açısından ele alan ilk kavramsal çalışmadan birisi olması sebebiyle literatüre katkı sağlayacağı açısından önemlidir. $\mathrm{Bu}$ çerçevede çalışmanın temel amacı, kaynak avantajı teorisi ve pazar yönlülüğün işletmelerin sürdürülebilir rekabet avantajı sağlamadaki rolünü kavramsal olarak incelemektir.

\section{REKABET AVANTAJI}

Rekabet avantaj1, bir işletmenin, sunmuş olduğu mal ve hizmetler sayesinde rakiplerin ve potansiyel müşterilerin gözünde konumlandığı maddi ve manevi üstünlük olarak ifade edilmektedir (Demir ve Demirel, 2011: 85). Rekabet avantajı kavramı ile ilgili literatürde yapılmış birçok çalışma yer almaktadır. Rekabet avantajı kavramını açıklamaya çalışan birden fazla kuramsal yaklaşım arasında pazar konumu ve endüstriyel yapıyı vurgulayan endüstri analizi yaklaşımı (Porter, 1980); yeni ekonomide öğrenen örgütlerin, bilgi üretmenin, kullanımının rekabet avantajı elde etmenin temeli olduğunu vurgulayan bilgi temelli yaklaşımlar (Senge, 1990) ve teknolojinin gelişmesiyle birlikte hızla değişen ve gelişen küresel pazarda, işletmelerin sahip olduğu benzersiz kaynaklar, temel yeterlilikler ve dinamik yetenekleri vurgulayan kaynak temelli yaklaşım (Barney, 1991; Teece vd., 1997) gibi yaklaşımlar öne çıkmaktadır.

Rekabet avantaj1 maliyet ve farklılik olarak iki temel boyutta incelenmektedir. Firmalar rakiplerine kıyasla müşterilerine sunduğu faydaları daha düşük maliyette sunabildiğinde maliyet avantajına sahip olurken, rekabet ettiği ürünlerin sahip olmadığı faydaları ve değerleri müşterilerine sunabiliyorsa da farkl11ık avantajına sahip olabilmektedir (Porter, 2008: 24). Rekabet avantajına farklı bir boyuttan bakan bir diğer yaklaşım ise kaynak temelli yaklaşımdır. Kaynak temelli yaklaşıma göre rekabet avantajı sağlamanın kritik faktörleri olarak işletmenin kaynakları ve yeteneklerine vurgu yapılmaktadır. Bu yaklaşıma göre işletmeler rekabet stratejilerini belirlerken, sadece diş çevre tarafından belirlenen unsurları dikkate almamalıdır. İşletmenin dış çevresinde gelişen faktörleri (potansiyel rakiplerin tehdidi, tedarikçilerin pazarlık gücü, ikame tehdidi) dikkate alıp, iyi analiz edip fırsatları değerlendirebilmesiyle birlikte, var olan kaynaklarını ve yeteneklerini de en iyi şekilde tanımlayıp kullanabilmesi rekabetçi avantaj sağlaması için oldukça önemlidir (Özbağ, 2016: 890).

$\mathrm{Bu}$ bağlamda artan küreselleşme ve gelişen rekabet ortamı içerisinde işletmeler rakiplerine kıyasla fark yaratabilmek ve avantajlı konuma geçebilmek için, maddi olmayan varlıkları ile ilgili konularda daha duyarlı davranmak ve bunun sürekliliğini sağlamak durumunda kalmaktadırlar (Demir ve Demirel, 2011: 83). Özellikle kaynak tabanlı görüşe göre rekabetçi avantaj sağlamada oldukça önemli bir unsur olan entelektüel sermaye kavramı 'işletme performansının kaynağı' ve 'rekabet avantajı elde etme yolunda önemli bir anahtar' olarak karşımıza ç1kmaktadır (Özbağ, 2016: 893). Şekil 1'de gösterilen model ise hem kaynak temelli hem de Porter'in jenerik rekabet stratejileri bakış açılarını birleştirilerek oluşturulmuş rekabet avantajı modelini göstermektedir (Bulut vd., 2004: 122). 
Mehmet Marangoz \& Tuğçe Merve İnak Özberk / Sürdürülebilir Rekabet Avantajı Sağlamada Kaynak Avantajı Teorisi ve Pazar Yönlülük Yaklaşımı

Şekil 1. Rekabet Avantaj1 Modeli

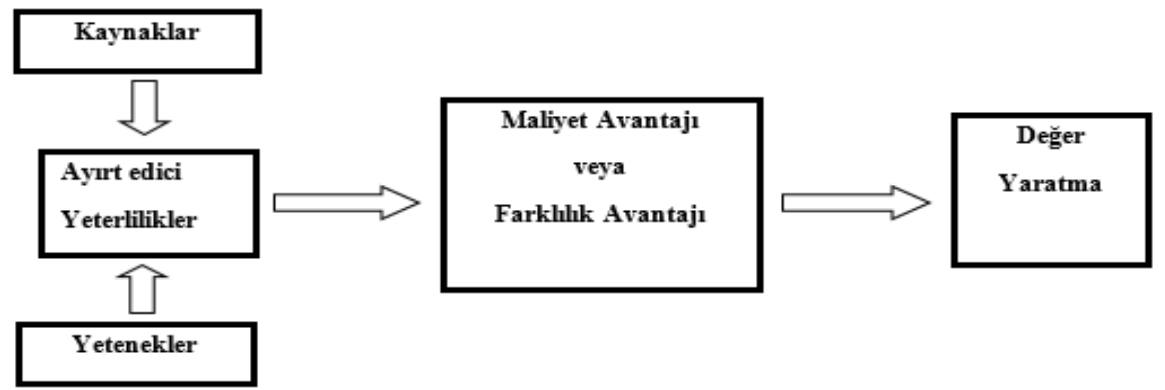

Kaynak: Bulut vd., 2004.

Şekil 1'de işletmelerin kaynaklarının ve yeteneklerinin işletmelere ayırt edici yeterlilik kazandırdığı bunun da işletmeye maliyet avantajı veya farklılık avantajı sağladığı belirtilerek bir değer meydana getirdiği ifade edilmektedir (Kaygın, 2012: 95). Küresel piyasa koşullarında bir işletme rakiplerine kıyasla aynı dönem içerisinde müşterilerine, öncesinde uygulanmayan ve yararlarının tekrarlanacağı bir değer oluşturma stratejisi ortaya koyabildiği takdirde, sürdürülebilir rekabet avantajına sahip olmaktadır (Demir ve Demirel, 2011: 86).

\section{KAYNAK AVANTAJI TEORISI}

Kaynak avantajı teorisi farklı disiplinlerin altyapısından geliştirilmiş disiplinlerarası bir evrimsel rekabet teorisidir. Hunt ve Morgan (1995) tarafindan ilk olarak ortaya atılan 'The comparative advantage theory of competition' isimli çalışmalarıyla literatüre kazandırdıkları bir teoridir (Hunt, 2015: 359).

Kaynak avantaji teorisi mikro ve makro anlamda pazarlama (Hunt ve Morgan (1995); Hunt (2011); Hunt (2015), yönetim (Hunt ve Lambe (2000), ekonomi (Hunt 2000; Hunt 2002); etik (Arnett ve Hunt (2002); genel işletme (Hunt, Arnett ve Madhavaram (2006) konularına odaklanır ve rekabet sürecini açıklamaya çalışır.

Kaynak avantaji teorisi işletmenin içsel analizi ile sektörün ve rekabet ortamının daha önceki stratejik yaklaşımların odak noktası olan dışsal analizini birleştirmiştir (Doğanay ve Kırçova, 2016: 30). Hunt (2012: 406) kaynak avantaj teorisini sadece farklı disiplinler arasında değil, değişik teorilerle bağlantısı olan evrimsel bir süreç teorisi olarak ifade etmiştir. Bununla beraber Hunt (2002: 239); teorinin pazarlama biliminin genel bir teorisi olmaya doğru ilerlediğini ifade etmiştir. Kaynak avantajı teorisine göre bazı pazar bölümleri içerisinde rekabetçi avantaj sağlayacak kaynaklara sahip olan işletmelerin, üstün pazar konumuna ve finansal performansa sahip olduğu ifade edilmektedir. Bu bağlamda kaynak avantajı teorisi, işletmeler arasındaki sürekli mücadele olarak tanımlanmaktadır (Topaloğlu, McDonald ve Hunt, 2018: 234).

İşletme kaynaklarının doğru anlaşılması, işletmeler için firsatların öngörülmesi ve stratejik karar alınması noktasında önemli bir etkiye sahiptir (Kayabaşı, 2007: 28) Günümüzde ise; örgüt içi kaynakların sürdürülebilir rekabet gücü yaratmadaki önemi yoğun bir şekilde ifade edilmektedir. Ayrıca, kaynak 
temelli teori işletmelerin taklit edilmesi zor ve kolaylikla transfer edilemeyen kaynaklarına odaklanır (Güleş ve Özilhan, 2010: 482).

Tam rekabetin olduğu bir piyasada, etkin bir kaynak dağılımı ile toplumsal refahın sağlanabileceği belirtilmektedir. Kaynak avantajı teorisi ise tam rekabetin tersine endüstri içindeki talebi tüketicinin zevklerine ve tercihlerine göre oldukça heterojen olarak ifade etmektedir. Bu bağlamda, aynı endüstrideki farklı pazar bölümleri için pazara farklı özelliklerdeki ürünlerin sunulması gerekmektedir (Güngör, 2016: 101).

Şekil 2. Kaynak Avantajı Teorisinin Şematik Gösterimi

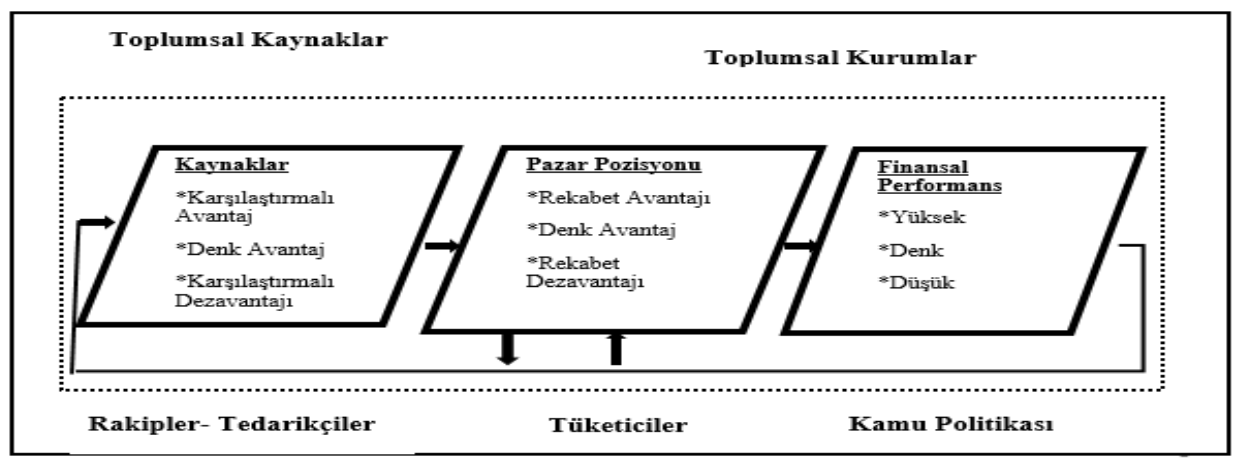

Kaynak: Bicen ve Hunt, 2012: 595; Hunt, 2015: 362.

Şekil 2'de kaynak avantajı teorisinin şematik olarak gösterimini görmek mümkündür. Pazar içerisinde her işletme kendine özgü bazı kaynaklara (etkili ve verimli bilgili çalışanlar, entelektüel sermaye, verimli üretim süreci gibi) sahip olarak kaynak avantajına sahip olmaktadır. Bu doğrultuda, işletmeler sektör içerisinde kaynak avantajına sahip olarak pazarda avantajlı bir pozisyon ve yüksek finansal performans elde etmektedir (Hunt, 2015: 361).

Diğer yandan kaynak avantajı teorisi işletmelerin sektör içerisinde pek çok yolla (pazar araştırması, kıyaslama, istihbarat arayışı gibi) yenilikçi girişime açık olduğunu ve öğrenmeye çalıştıklarını ifade etmektedir (Hunt, 2011: 9). Şekil 2'de de görüldüğü gibi geribildirim döngüsüyle firmalar rekabet sürecinde; göreceli kaynakları işaret eden göreceli pazar pozisyonundan gelen finansal başarı ya da başarısızlık durumunu bu doğrultuda öğrenebilirler.

\section{KAYNAK AVANTAJI TEORISII VE SÜRDÜRÜLEBİLÍR REKABET AVANTAJI}

Sürdürülebilir rekabet avantajı düşüncesi 1984 yılında Day’in sürdürülebilir rekabet avantajını sağlayan strateji türlerini ifade ettiği dönemde gündeme gelmiştir (Taşkın, Kayabaşı ve Kiracı, 2011: 107). Ardından sürdürülebilir rekabet avantajı kavramı ilk olarak Porter tarafından ifade edilmiştir. Porter (1985)'e göre sürdürülebilir rekabet avantaj1, işletmelerin uzun dönemde ortalamanın üzerinde performans sergilemesidir (Porter, 1985: 11). Bir başka tanıma göre ise sürdürülebilir rekabet avantajı "bir işletmenin, mevcut ya da potansiyel rakipleri tarafindan ayni zamanda uygulanamayan ve kopyalanamayan, değer yaratan bir strateji uygulaması" olarak ifade edilmektedir (Barney, 1991: 102). 
Ayrıca işletmelerin sürdürülebilir rekabetçi üstünlüğe sahip olabilmeleri için kaynak ve yeteneklerinin dört temel özelliğe sahip olmaları gerekir. $\mathrm{Bu}$ özellikler; kaynakların kalıcı ve ömrünün uzun olması, kaynağın tam olarak rakipler tarafından bilinmemesi, sahip olunan kaynağın direkt bir başka işletmeye transfer edilememesi ve tam olarak kopyalanamaması olarak belirtilmektedir (Grant, 1991: 134). Günümüzde pazarlama anlayışının müşteri odaklı felsefesi, pazar bölümlendirme, konumlandırma, ürün yaşam döngüsü gibi olgular stratejik yönetim düşüncesini de doğrudan etkilemiştir. Stratejik yönetim literatüründe rekabet avantajı teorisi olarak da ifade edilen kaynak avantajı teorisi istenilen düzeyde yönetsel çabaların firmalara sürdürülebilir rekabet avantajı yaratacağını ifade etmektedir (Güleş ve Özilhan, 2010: 482). Dolayısıyla yukarıdaki dört özelliğe sahip olabilmek için stratejik yönetim bakış açısına sahip olmak önemlidir.

Kaynak avantajı teorisi bağlamında sürdürülebilir rekabet avantajının elde edilmesi için belli koşulların gerçekleşmesi gerekmektedir. İlk koşul olarak işletmeler bünyelerinde bulundurdukları kaynak ve yetenekleri vasitasıyla müşterilerine değer yaratmasını başarmalıdır. İkinci koşul olarak ise diğer rakip işletmelerden farklı kaynak ve yeteneklere sahip olmaları gerekmektedir (Koçak vd., 2005: 183). Bununla beraber, kaynak avantajı teorisi bağlamında işletmelerin yeteneklerinin rakipleri tarafından elde edilme olasılığ işletmelerin sürdürülebilir rekabet avantajı sağlayacak konuma geldiği belirtilebilmektedir (Mata vd., 1995: 491).

Tablo 1. Rekabetçi Pozisyon Matrisi

\begin{tabular}{|c|c|c|c|c|}
\hline \multirow{5}{*}{$\begin{array}{c}\text { Göreceli } \\
\text { Kaynak } \\
\text { Maliyetleri } \\
\text { (Verimlilik) }\end{array}$} & \multicolumn{4}{|c|}{ Göreceli Kaynak-Üretim Değeri (Etkililik) } \\
\hline & & Düşük & Eşitlik & Üstün \\
\hline & Düşük & $\begin{array}{l}\text { 1-Belirsiz } \\
\text { Pozisyon }\end{array}$ & $\begin{array}{l}\text { 2-Rekabetçi } \\
\text { Avantaj }\end{array}$ & 3-Rekabetçi Avantaj \\
\hline & Eşit & $\begin{array}{l}\text { 4-Rekabetçi } \\
\text { Dezavantaj }\end{array}$ & 5-Eşitlik Pozisyon & 6-Rekabetçi Avantaj \\
\hline & Üstün & $\begin{array}{l}\text { 7-Rekabetçi } \\
\text { Dezavantaj }\end{array}$ & $\begin{array}{l}\text { 8-Rekabetçi } \\
\text { Dezavantaj }\end{array}$ & 9-Gelirsiz Pozisyon \\
\hline
\end{tabular}

Kaynak: Hunt, 2015: 363.

Tablo 1'de görüldüğü gibi işletmeler göreceli kaynak üstünlüklerine sahipse (bilgili çalışanlar ve kolay kopyalanamaz üretim süreci gibi) ve bu kaynakları maliyetleri de göreceli olarak düşükse piyasada rekabetçi avantaja sahip olmaktadır (Hunt, 2015: 370). Bu bağlamda, yukarıda belirtilen koşullar sağlandığ takdirde işletmeler, kaynakları eşsiz, taklit edilmesi zor ve değerli ise sürdürülebilir rekabet avantajına sahip olabileceklerdir.

Hunt, (2012) ve Hunt ve Morgan, (1996) kaynak avantajı teorisinin temel unsurlarını; talep, tüketici bilgisi, insan güdüsü, işletme amacı, işletme bilgisi, işletme kaynakları, yönetimin görevi ve rekabet dinamikleri olarak ifade etmektedirler.

\section{A. Talep}

Kaynak avantajı teorisi içerisinde sürdürülebilir rekabet avantajı sağlamada önemle değerlendirilmesi gereken husus talep unsuru olarak karşımıza çıkmaktadır. Kaynak avantajı teorisine göre endüstri içi talebin hem büyük ölçüde heterojen hem de dinamik olduğu düşünülmektedir. Ürün kategorilerine göre sektör ve pazar 
bölümlerinde tüketici talepleri ve tercihleri büyük ölçüde farklilıklar göstermektedir (Hunt, 2015: 371).

Kaynak avantajı teorisi kâr amacı gütmeyen kuruluşlar bağlamında değerlendirildiğinde, müşteri taleplerinin de hem endüstri içi hem de endüstri dış1 dinamik ve heterojen olduğunu kabul etmektedir (Topaloğlu, McDonald ve Hunt, 2018: 236) Benzer şekilde kar amacı gütmeyen kuruluşlar tarafından sağlanan pazar tekliflerine olan talep de heterojendir. Talebin bu heterojenliği, benzersiz bireysel ihtiyaç veya tercihlerden kaynaklanabilir (Corbin, 1999: 296). Bu bağlamda, talebin büyük ölçüde heterojen oluşu kaynak avantajı teorisinde, işletmelerin pazar pozisyonlarındaki finansal performansın değerlendirilmesi hususunda katkida bulunur.

\section{B. Tüketici Bilgisi}

Kaynak avantajı teorisi içerisinde sürdürülebilir rekabet avantajı sağlamada değerlendirilmesi gereken bir diğer unsur tüketici bilgisi olarak ifade edilmektedir. Günümüzde hızla değişen pazar koşullarına göre kaynak avantajı teorisi bağlamında ifade edilen, talebin endüstriler arasında farklılaştığ 1 ve tüketici bilgisinin eksik ve maliyetli olduğu tezlerinin geçerli olduğunu söylemek mümkündür (Yalçın, 2010: 66). Tüketicilerin eksik ve kusurlu bilgiye sahip olmaları kaynak avantajı teorisi için bir sorun değildir. Aksine şirketler tüketicilerin kusurlu bilgilerinden faydalanıp, bu durumu kalite ve marka algısına çevirerek kendi avantajlarına kullanabilmektedir (Hunt, 2015: 372-373).

Nelson (1970: 311) kaynak avantajı ile ilgili çalışmasında müşterilerin mal ve hizmetlerle ilgili bilgilerinin eksik olduğunu belirtmektedir. Bununla birlikte, iş dünyasında olduğu gibi kâr amacı gütmeyen kişi veya kuruluşların ulaşmaya çalıştı̆̆ bireyler kusurlu ve maliyetli bilgilere sahip olabilmektedir. Örneğin, hayır kurumuna para bağışlamak isteyen biri, bir bağışın belirli bir kuruluş üzerindeki olas1 etkisi hakkında mükemmel bir tüketici bilgisine sahip olmayabilir (Chetkovich ve Frumkin, 2003: 564).

Bu bağlamda, kaynak avantajı teorisine göre tüketicilerin eksik bilgiye sahip olması olası bir durumdur. Sonuç olarak, kaynak avantajı teorisi işletmelerin statik denge verimliliğini reddettiği için, tüketici bilgi eksikliğini, talep ve arzın heterojenliğini bir sorun olarak görmeyip, piyasalar içerisinde arzu edilen bir durum olarak ifade etmektedir (Hunt, 2015: 372).

\section{C. İnsan Motivasyonu}

Kaynak avantajı teorisinin temel tezleri içerisinde vurgulanan bir diğer önemli husus, insan motivasyonunun alışılmadık ve bencilce olduğudur. Kaynak avantajı teorisine göre insan motivasyonu en iyi kısıtlanmış kişisel çıkar arayışı olarak ifade edilmektedir (Hunt, 2015: 373). Kaynak avantajı teorisine göre insan motivasyonu; toplumsal, profesyonel, endüstriyel veya örgütsel ahlak kurallarının şekillendirdiği kişisel ahlaki kurallar tarafından sınırlanan kişisel çıkar arayışıdır (Hunt, 2000: 77).

Ayrıca, Topaloğlu vd. (2018) çalışmalarında kâr amacı gütmeyen kuruluşlarda insan motivasyonunun; kişisel çıkarlar, etik standartlarla da sınırlanan bir sosyal misyonun peşinden koşularak ortaya çıkabildiğini ifade etmektedir 
(Topaloğlu vd., 2018: 237). Laverie ve McDonald (2007: 274) çalışmalarında ise gönüllüler için kimliklerinin öneminin, onlar için önemli bir motivasyon kaynağ1 olduğunu ifade etmektedir.

Kaynak avantajı teorisine göre insan motivasyonu kişisel ahlaki kurallarla sınırlandırılan bir ilgi alanı olarak tanımlanmaktadır. Bu doğrultuda, kaynak avantajı teorisi, faaliyetlerin doğruluğunu temel alan (deontolojik) etiği vurgulayan, ahlaki kurallar tarafından motive edilmiş bireylere sahip olan işletmelerin ve toplumların ekonomik değerlerinin açılanabileceğini belirtmektedir (Hunt, 2015: 374-376).

\section{D. İşletme Amacı ve Bilgisi}

Kaynak avantajı teorisi firmanın temel amacını, mevcut ve potansiyel pazar bölümleri, rakipler, tedarikçiler, paydaşlar ve üretim teknolojileri hakkında kusurlu ve çoğu zaman elde edilmesi gereken bilgiler altında kazandığı üstün finansal performans olarak ifade etmektedir (Hunt, 2011: 72).

Ayrica üstün finansal performans sergileyen işletmelerin sahiplerine, yöneticilerine ve çalışanlarına kaynak avantajı teorisinin kabul gördüğü gibi insan davranışının kişisel çıkar arayışına uygun olarak ödüllendirmeler (maaş, ikramiye, prestij ve başarı duyguları) dağıtılır (Hunt, 2015: 377). Kaplan (2001) ise, kâr amacı gütmeyen kuruluşlar için başarının, finansal önlemlerden ziyade seçmenlerinin ihtiyaçlarını ne kadar verimli bir şekilde karşıladıklarıyla ölçülmesi gerektiğini savunmaktadır. Sonuç olarak, kaynak avantajı teorisine göre işletmeler en azından yeterli finansal performansta olmalı; başka bir deyişle, organizasyon, organizasyonun devamını sağlayan bir finansal performans seviyesine ulaşmalıdır (McDonald vd., 2015: 970).

\section{E. Kaynaklar}

Kaynak avantajı teorisine göre kaynaklar finansal, fiziksel, yasal, insani, örgütsel, bilgi ve ilişkisel boyutları çerçevesinde sınıflandırılmaktadır (Hunt, 2015: 381; Topaloğlu vd., 2018: 239).

Finansal kaynaklar bir işletmenin elinde bulundurduğu kapital güçtür ve genel olarak finansal kaynaklar hareketlidir. Çünkü finansal kaynaklar piyasada başka kaynaklarla ticaret yapılarak elde edilebilir. Yasal kaynaklar, kuruluşun benzersiz bir şekilde sahip olduğu varlıklardır. Devlet tüzüğü veya kuruluş ile başka bir taraf arasında yasal olarak bağlayıcı bir anlaşma nedeniyle işletmeler yasal kaynaklara sahip olmaktadır (Morgan ve Hunt, 1999: 283).

Fiziksel kaynaklar, bir kuruluşun mal ve hizmetlerini üretmek ve pazarlamak için kullanılan maddi varlıklardır. Bunlar arasında hammadde rezervleri, makine, arazi ve işletme, üretim, depolama, dağıtım, servis ve perakende satış tesisleri bulunmaktadır (Morgan ve Hunt, 1999: 284). Insan kaynakları ise, kurum çalışanlarının becerilerini, bilgilerini ve vizyonunu kapsar (Hunt, 2000: 77). Kısacası işletmelerin sürdürülebilir rekabet üstünlüğüne sahip olmasında önemli bir rol oynayan insan kaynaklarını, işletmelerin entelektüel sermayeleri olarak da ifade etmek mümkündür.

Bununla birlikte örgütsel kaynaklar; kurum kültürü, imajı ve kurumun yapısı gibi organizasyonun kendisinden doğan varlıklara aittir. Ayrıca işletmelerin 
ortak bilgisi ve örgütsel öğrenmeyi teşvik etmek için geliştirilen süreçler bir organizasyonun bilgi kaynaklarını içerir (Morgan ve Hunt, 1999). Bilgi kaynakları arasında pazar bölümleri, rakipler, teknoloji ve kuruluşlardan bilgi toplamak, yaymak ve uygulamak için geliştirdikleri sistemler bulunur. Son olarak Ilişskisel kaynaklar ise işletmelerin organizasyon içinde ve organizasyon ile çeşitli diş ortakları arasında arasındaki ilişkileri ifade eder (Topaloğlu vd., 2018: 242)

Kısaca inovasyon ve örgütsel öğrenme yoluyla, işletmeler sürdürülebilir rekabet avantajına sahip olmaya çalışarak, konumlarını ilerletmek için rakiplerinin kaynaklarını edinir, taklit eder, ikame eder veya onlardan daha fazla kazanırlar (Peranginangin, 2015: 143). Bu nedenledir ki, işletmelerin bünyelerinde sahip oldukları kaynaklar, sektör içerisinde onlara sürdürülebilir rekabet avantajı sağlayarak daha iyi pazar pozisyonlarına sahip olmayı sağlayabilir.

\section{F. Yönetimin Rolü}

Kaynak avantaj teorisine göre yönetimin işletmelerdeki rolü, mevcut stratejileri tanımak ve anlamak, yeni stratejiler oluşturmak, tercih edilen stratejileri seçmek, seçilen stratejileri uygulamak ve zaman içinde stratejileri değiştirmektir. Hunt (2015: 383)'e göre ise tüm stratejiler iş birimi düzeyinde (1) pazar bölümleri, (2) uygun pazar teklifleri ve (3) gerekli kaynakları belirlemeyi içermektedir. İşletmelerin sürdürülebilir rekabet avantajını ve sürdürülebilir üstün finansal performans1 elde edebilmeleri ancak başta üst düzey yöneticilerin kişisel ahlaki değerlerini koruyarak, işletmelerin karşılaştırmalı üstün kaynaklara sahip olmalarıyla mümkündür.

Kaynak avantaj1 teorisi diğer rekabet teorilerinden farklı olarak sürdürülebilir rekabet avantajını elde ederken işletmelerin ahlaki boyuttaki değerlere önem vermesi gerektiğinin vurgusunu yapmaktadır (Doğanay ve Kırçova, 2016: 31).

\section{G. Rekabet Dinamikleri}

Kaynak avantaj1 teorisi açısından rekabet, işletmelerin hareketlerinin dengesizliğini tetiklediği evrimsel bir süreçtir. $\mathrm{Bu}$ süreçte, inovasyon iç kaynaklı bir oluşumdur. Bu bağlamda kaynak avantajı teorisi rekabet dinamikleri olarak; çevre koşullarının, özellikle endüstrinin yapısının, işletmelerin davranışını (stratejisini) ve performansını (kârlarını) kesin bir şekilde belirlediğini ifade etmek mümkündür (Peranginangin, 2015: 144).

Kaynak avantajı teorisine göre bir sektördeki tüm işletmeler aynı stratejiyi kabul etmemektedir. Teoriye göre farklı kaynak çeşitlerine sahip işletmeler, farklı pazar bölümlerini belirleyerek, rakiplerine göre farklı rekabet dinamikleri doğrultusunda stratejilerini belirlemelidir. Bu bağlamda, kaynak avantaji teorisi yukarıda belirtilen rekabet dinamiklerini yönetirken; süreç içerisinde işletmelerdeki kaynakları verimli bir şekilde tahsis eder. Bununla beraber, rekabet süreci içerisinde yeni kaynaklar yarattığ için şirketlerde verimlilik artar ve ekonomik büyüme gerçekleşmiş olur (Hunt, 2015: 384).

Günümüz rekabet koşulları içerisinde işletmeler içerisinde pazar bilgisini kullanma ve bu bilginin operasyonlara yön vermesiyle ilgili pazarlama yetenekleri, çok önemli ve değerli bilgi kaynağını temsil ettiğini belirtilmektedir. Bu 
doğrultuda, işletmelerin stratejik kararlarında pazar yönlü bir yaklaşıma sahip olmaları özellikle yeni ürünlerin başarısını olumlu yönde etkilemektedir (Baker ve Sinkula, 2005: 483). Bu bağlamda, pazar yönlü bir işletmenin sahip olduğu yenilikçi kültürün, değer yaratma kapasitesini etkilediğini ve bu anlamda işletmelerin sürdürülebilir rekabetçi avantaja sahip olmasını sağladığını söylemek mümkündür.

\section{PAZAR YÖNLÜLÜK}

Pazar yönlülük (pazar odaklılık) modern pazarlama anlayışının başlangıcı olarak kabul edilen 1990'lardan sonra birçok araştırmacı tarafından ele alınan bir konu olmuştur (Ekber ve Ahmadov, 2017: 34). Literatürde pazar yönlülük kavramı birçok araştırmacı tarafından açıklanmaya çalışılsa da, pazar yönlülügüün kapsamını, yapısını ve hangi unsurları ele aldığını en iyi açıklayan çalışmalar Kohli ve Jaworski (1990) ile Narver ve Slater (1990)'ın çalışmaları olduğunu söylemek mümkündür.

Kohli ve Jaworski (1990) çalışmalarında pazar yönlülüğü pazarlamanın uygulaması olarak ifade etmektedir. Eğer bir işletme pazar yönlü ise; müşterilerinin mevcut ve ileride olabilecek istek ve ihtiyaçlarını anlamlandırmaya yönelik davranışlar sergileyeceğini belirtmektedirler. Bu bağlamda pazar yönlülük; pazar bilgisi üretme, pazar bilgisinin yayılması ve pazara cevap verebilme şeklinde üç temel boyutta incelenmektedir (Kohli ve Jaworski, 1990: 1-6).

Narver ve Slater (1990) ise çalışmalarında pazar yönlülüğü; müşteriler için etkin ve verimli şekilde değer yaratacak faaliyetleri içeren bir işletme kültürü olarak ifade etmektedir. Kültürel yaklaşım olarak da ifade edilen yaklaşıma göre; bir işletmenin en önemli hedefinin karlılık olduğu ve üstün performans ile rakiplerine kıyasla sürdürülebilir rekabet avantajını yakalaması gerektiği belirtilmektedir. $\mathrm{Bu}$ bağlamda pazar yönlülük davranışsal açıdan üç temel boyutta incelenmektedir. Bunlar müşteri yönlülük, rakip yönlülük ve davranışsal unsur olan fonksiyonlar arası koordinasyondur (Ayyıldız Ünnü, 2009: 1249). Tablo 2'de ise pazar yönlülük ile ilgili yapılan bazı çalışmalar ve pazar yönlülük ile ilgili yaklaşımları toplu olarak görmek mümkündür.

Tablo 2. Pazar Yönlülük ile İlgili Yapılan Bazı Çalışmalar ve Yaklaşımlar

\begin{tabular}{|c|c|}
\hline Yazarlar & Pazar Yönlülük ile İlgili Yaklaşımlar \\
\hline \multirow{3}{*}{$\begin{array}{l}\text { Kohli ve Jaworsk } \\
\text { (1990) }\end{array}$} & Pazar bilgilerinin işletmenin örgütü tarafindan toplanması \\
\hline & Pazar bilgilerinin işletme örgütü içerisinde yayılması \\
\hline & Pazar bilgisine örgüt çapında karşılık verilmesi \\
\hline \multirow{3}{*}{$\begin{array}{c}\text { Narver ve Slater } \\
\text { (1990) }\end{array}$} & Müşteri odaklılık \\
\hline & Rakip odaklılık \\
\hline & Fonksiyonlar Arası \\
\hline \multirow[t]{3}{*}{ Deng ve Dart (1994) } & $\begin{array}{l}\text { Müşterilerin mevcut ve tahmini gelecekteki ihtiyaçlarına ilişkin uygun pazar } \\
\text { bilgilerinin toplanması }\end{array}$ \\
\hline & $\begin{array}{l}\text { Bu istek ve ihtiyaçları sağlayabilmek için rekabetçi unsurlarda ilgili kaynak ve } \\
\text { yeteneklerin elde edilmesi }\end{array}$ \\
\hline & Departmanlar arası bilgilerin yayılması ve entegre edilmesi \\
\hline \multirow[t]{2}{*}{$\begin{array}{l}\text { Hunt ve Morgan } \\
\text { (1995) }\end{array}$} & $\begin{array}{l}\text { Mevcut veya gelecekte olabilecek potansiyel müşteriler ve rakiplerle ilgili olarak } \\
\text { bilgilerin düzenli olarak toplanması }\end{array}$ \\
\hline & $\begin{array}{l}\text { Pazar ile ilgili düzenli gelen bilginin anlamlandırılıp geliştirilmesi ve bilginin } \\
\text { sistematik olarak analiz edilmesi }\end{array}$ \\
\hline
\end{tabular}




\begin{tabular}{|c|l|}
\hline \multirow{2}{*}{} & $\begin{array}{l}\text { Pazar ile ilgili gelen bilginin yaratılmasına, tanımlanmasına, anlamlandırılmasına, } \\
\text { seçimine, örgüte uygulanmasına ve işletme örgütü içerisine yerleştirilmesine } \\
\text { rehberlik etmesi için sistematik kullanımı }\end{array}$ \\
\hline Langerak (2001) & $\begin{array}{l}\text { Müşteri değerini ve bu pazardaki rakiplerin yetenek ve stratejilerini anlamak için } \\
\text { gerekli bilgilerin toplanması }\end{array}$ \\
\cline { 2 - 2 } & Bilgilerin dağıtılması \\
\cline { 2 - 2 } & İşletme fonksiyonlarının koordinasyonlu bir biçimde çalışması \\
\hline $\begin{array}{c}\text { Narver, Slater ve } \\
\text { MacLachlan (2004) }\end{array}$ & Pazar yönlülüğü özellikle yenilik performansı ile değerlendirerek tekrar ele almıştır. \\
\cline { 2 - 2 } & $\begin{array}{l}\text { Pazar yönlülük; proaktif pazar yönlülük ve duyarlı pazar yönlülük olarak iki temel } \\
\text { boyutta incelenmiştir. }\end{array}$ \\
\hline
\end{tabular}

Kaynak: Yazarlar tarafından oluşturulmuştur.

Daha önce pazar yönlülük ile ilgili yapılan çalışmalarda (Şahin, 2018; Chia Wu, 2017; Ekber vd., 2017; Eren vd., 2013; Ayyıldız Ünnü, 2009; Karahan ve Özçiftçi, 2008) pazar yönlülügün işletme performansı ve rekabet avantajı açısından önemi vurgulanmaktadır.

Tablo 2'de de görüldüğü gibi pazar yönlülük ile ilgili birçok çalışma yapılmış ve farklı görüşler ortaya atılmıştır. Bu çalışmada ise Narver ve Slater (1990)'nn görüssleri doğrultusunda pazar yönlülük (1) müşteri yönlülük, (2) rakip yönlülük, (3) fonksiyonlar arası koordinasyon olarak üç temel boyutta ele alınmakta ve değerlendirilmektedir.

\section{A. Müşteri Yönlülük}

Müşteri yönlülük; işletmenin müşterilerin istek ve ihtiyaçlarına göre onlara değer yaratacağı ürün ve hizmetleri sağlayabilmesi için yeterli düzeyde bilgiye ve deneyime sahip olması olarak ifade edilmektedir (Narver ve Slater, 1994: 334). Bir diğer ifadeyle müşteri yönlülük, sürekli olarak müşteri değeri yaratmak için müşteriyi yeterince anlama olarak da tanımlanmaktadır (Karahan ve Özçiftçi, 2008: 480).

Günümüzde pazar yönlülük özellikle müşteri yönlülük ve yenilik performansı ile değerlendirilerek ele alınan konular arasındadır (Narver, Slater ve MacLachlan, 2004: 334). Pazar yönlülük; proaktif pazar yönlülük ve duyarlı pazar yönlülük olarak iki temel boyutta incelenmektedir. Proaktif pazar yönlülük müşterilerin istek ve ihtiyaçlarına karşın ortaya çıkaramadığı, belirsizlik içeren ihtiyaçların tahmini ve tatmini noktasında davranışların bütünü olarak ifade edilirken; duyarl pazar yönlülük ise müşteri tarafından belirtilen mevcut tespit edilmiş müşteri istek ve ihtiyaçlarını karşılamaya yönelik olarak ifade edilmektedir (Şahin, 2018: 679). Bu bağlamda, geçmişte pazar yönlülük genel olarak duyarlı pazar yönlülük açısından müşterinin mevcut istek ve ihtiyaçlarına göre belirtilirken, günümüzde proaktif pazar yönlü yaklaşım ile müşterinin ileriye dönük keşfedemediği istek ve ihtiyaçlarının karşılanması ve yenilikçi faaliyetlerin gerçekleşmesi olarak belirtilmektedir.

\section{B. Rakip Yönlülük}

Rakip yönlülük; işletmenin mevcut ve ileride olabilecek rakiplerine güçlü, zayıf yönlerini, firsat ve tehditlerini değerlendirerek, rakiplerinin uzun vadeli stratejilerini anlamlandırmanın gerekliliğini belirtmektedir (Narver ve Slater: 1990: 21). Bu bağlamda rakip yönlülükle, işletmelerin rakipleriyle ilgili olarak önem vermesi gereken hususlar (Narver, Slater ve MacLachlan, 2004: 335); 
- Rakiplerin büyüklüğü ve pazar payı, büyüme hızı ve karlılığa göre siniflandirılmasi,

- Rakiplerin organizasyonu, kurumsal yap1, kültür, yönetim sistemleri ve çalışanların becerileri,

- Rakiplerin genelde güçlü ve zayıf noktaları şeklinde sıralanabilir.

Yukarıda belirtilen hususlar doğrultusunda günümüzde çağdaş pazar yönlü, müşteri odaklı işletmeler veya kâr amacı gütmeyen örgütler, bütün çabalarını ve faaliyetlerini rakiplerine göre müşteriye değer yaratmak adına gerçekleştirmektedir (Tek, 2004: 7).

Bu bağlamda, pazar yönlülük yaklaşımıyla birlikte işletmeler, rakiplerinin piyasadaki pozisyonlarıyla alakalı bilgi sahibi olabilmektedir. Ayrica hem rakiplerin hem de müşterilerin ihtiyaçlarındaki değişmeleri ve gelişmeleri kestirerek, yeni ürün ya da hizmet geliştirme noktasında stratejilerini belirlemektedir (Narver ve Slater: 1995: 63). Sonuç olarak, rakip yönlülük ile birlikte işletmeler, mevcut ve potansiyel rakiplerinin kısa dönem güçlü ve zayıf yönlerini, uzun dönem yetenek ve stratejilerini anlayarak bu doğrultuda gelecekteki adımlarını atabilmektedir (Slater ve Narver, 1994: 3).

\section{Fonkyonlar Arası Koordinasyon}

Pazar yönlülük içerisinde Narver ve Slater'1n önemle vurguladığı son boyut ise fonksiyonlar arası koordinasyondur. $\mathrm{Bu}$ süreçte işletmeler bünyelerindeki kaynakları müşteriye en iyi değeri yaratabilmek adına organize ederek, işletme fonksiyonları arasındaki koordinasyonu dengeli bir biçimde uygulamalıdır (Narver ve Slater: 1995: 64).

$\mathrm{Bu}$ bağlamda, etkin ve verimli müşteri değerini oluşturmak için işletme içerisindeki tüm departmanlar, hem müşteri istek ve ihtiyaçlarına yoğunlaşarak hem de işletme içi diğer tüm fonksiyonların ihtiyaçlarına duyarlı olan bir süreci yönetmelidir (Narver ve Slater, 1990: 21-24). Ayrıca, pazar yönlülük işletmelerin örgüt yapılarında rakipleri tarafından taklit edilmesi zor bir içsel güç ve işletmelere sürdürülebilir rekabetçi avantaj kazandıran bir kaynak olarak belirtilmektedir (Hunt, 2015: 413).

Fonksiyonlar arası koordinasyonu iyi sağlayan pazar yönlü işletmeler, faaliyet gösterdiği pazarlarda müşteri ihtiyaçlarını, tedarikçilerin ve rakiplerin faaliyetleri ile ilgili bilgileri etkin bir şekilde toplayıp, bu bilgileri şirket içindeki ilgili birimlere dağıtarak, bu doğrultuda pazara ve müşterilerine beklenilen müşteri değerini etkin bir şekilde sunabilmektedir (Durukan ve Hamşioğlu, 2015: 6).

\section{KAYNAK AVANTAJI VE PAZAR YÖNLÜLÜK İLE SÜRDÜRÜLEBİLIR REKABET AVANTAJI SAĞLAMA}

Sürdürülebilir rekabet avantajı sağlamada pazar yönlü olmak önemli bir pazarlama kültürü olarak karşımıza çıkmaktadır (Barney, 1986: 657). Bir anlamda işletmeler için pazar yönlü olmak, sürdürülebilir rekabet avantajının korunması ve işletmelerin rakiplerine karşı taklit engellerini ve izolasyon mekanizmalarını oluşturmalarını sağlar (Hamşioğlu ve Durukan, 2018: 5).

Kaynak avantaj1 teorisini ortaya atan Hunt ve Morgan (1995); Narver ve Slater (1990)'nın pazar yönlülük ile ilgili görüşlerini desteklemektedir. Pazar 
unsuru olarak hem müşterileri hem de rakipleri ifade ederek, pazar yönlülüğün her iki tarafla ilgili olduğunu savunmaktadır. Bu bağlamda Hunt ve Morgan, (1995:1) ile Hunt ve Madhavaram, (2006: 99) pazar yönlülüğ̈̈;

- Mevcut ve potansiyel müşteriler ve rakipler hakkında bilgilerin sistematik olarak toplanmas1,

- Pazar bilgisinin geliştirilmesi amacıyla bilginin sistematik analiz edilmesi,

- Bu bilginin strateji tanımlanmasına, anlaşılmasına, yaratılmasına, seçimine, uygulanmasına ve modifiye edilmesine rehberlik etmesi için sistematik kullanımı olarak ifade etmektedir.

İşletmelerin sürdürülebilir rekabet avantajına sahip olmasında işletmelerin fiziksel olmayan kaynaklarının etkisi büyüktür. Bu kaynaklar pazar tabanlı kaynaklar olarak ifade edilmektedir. Pazar tabanlı kaynaklar içerisinde yer alan entelektüel kaynaklar, işletmenin çevresi ile ilgili rakipler, müşteriler, tedarikçiler, sosyal ve politik çıkar grupları gibi sahip olduğu her türlü bilgiyi içerirken; ilişkisel kaynaklar ise, işletmenin önemli dış paydaşları (aracılar, perakendeciler, müşteriler, stratejik ortaklar, toplum grupları, devlet gibi) ile olan ilişkiler olarak ifade edilmektedir. Pazarlama bakış açısıyla, pazar tabanlı kaynaklar örgüt içinde pazarlamacılar ve diğer işletme birimleri tarafından kullanılabilen, değerli çıktılar yaratabilen varlıklardır (Hunt, 2012: 406).

Bu bağlamda, Şekil 3'deki unsurların pazar tabanlı kaynaklar içerisinde yer aldığını görerek, işletmelerin sürdürülebilir rekabet avantajına sahip olabilmeleri için pazar yönlü stratejileri içerisinde taklit edilmesi zor ve fiziksel olmayan pazar tabanlı kaynaklarını stratejik anlamda iyi kullanması gerekmektedir.

Şekil 3: Sürdürülebilir Rekabet Avantajı Sağlamada Kaynak Avantajı Teorisi ve Pazar Yönlülük

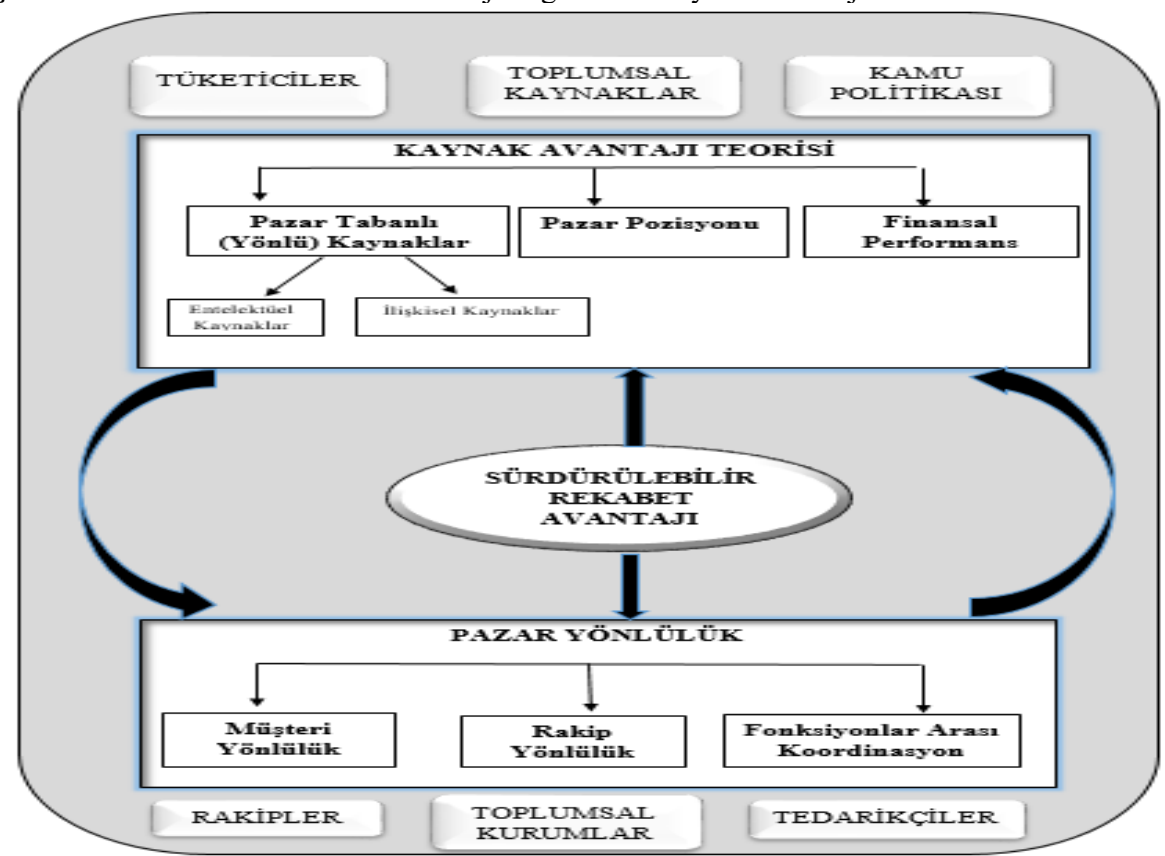

Kaynak: Kocak vd. 2005:181'den geliştirilmiştir. 
Sürdürülebilir rekabet avantajı sağlamada hem kaynak avantajı teorisinin hem de pazar yönlülük yaklaşımının işletmelere çok yönlü fayda sağladığını söylemek mümkündür. Şekil 3'de kaynak avantajı teorisi ve pazar yönlülük unsurlarının işletmelere sürdürülebilir rekabetçi avantaj sağlamadaki ilişkileri görülmektedir. $\mathrm{Bu}$ bağlamda, kaynak avantajı teorisi ve pazar yönlülük işletmelerde sürdürülebilir rekabet avantajı sağlamaya farklı boyutlarda katkı sağlayan unsurlardır. Bir bakıma işletmeler için pazar yönlülük bir tür yenilenme yetkinliği olarak görülmektedir. Yani kaynak avantajı teorisine göre, pazar yönlülük işletmelere bir tür yetkinlik kılarak proaktif inovasyonu teşvik etmektedir (Hunt, 2015: 413). İşletmeler pazar yönlülük ile birlikte, potansiyel pazar bölümlerini öngörerek ve bu tür bölümlere cazip gelebilecek pazar tekliflerini oluşturup, müşterilerin şu an ve ilerideki istek ve ihtiyaçlarına göre kaynaklarını etkin bir şekilde kullanabilmektedirler (Hunt ve Madhavaram, 2006: 99).

Pazar yönlülük, müşteri yönlülük, rakip yönlülük ve hedef müşterilere üstün değer yaratmak için işletme kaynaklarının kullanımını organize eden işlevsel bir koordinasyon oluşturmaktadır. Ayrıca pazar yönlülük, işletmelerin strateji seçimine de yardımcı olmaktadır. Bu durum ise, müşterilerin isteklerine daha iyi karşılık verme, rakipler karşısında en iyi örgüt stratejinin belirleme, rekabetçi üstünlüğün sürdürülmesine ve işletme performansının uzun erimli artmasına öncülük eder. İşletmelerin bunu başarabilmesi için pazar yönlülüğü benzersiz bir kaynak olarak görmeleri gerekir ve bu yönüyle pazar yönlülük sürdürülebilir rekabetçi üstünlük yaratan önemli bir kaynak olarak karşımıza çıkmaktadır (Hamş10ğlu, 2018:438-439).

Koçak vd. (2005)'e göre, pazar odaklilıkta işletmenin sürdürülebilir rekabet avantajı sağlayabilmesi için, pazardaki mevcut ve potansiyel müşteri ihtiyaçlarının belirlenmesi ve elde edilen bilginin tüm işletme fonksiyonları tarafından paylaşılarak, ihtiyaçların rakiplerden daha iyi bir şekilde karşılanması görüşü hakimken, kaynak temelli yaklaşımda rekabet avantajı sağlamanın işletmenin kaynaklarına ve kabiliyetine bağlı olduğu görüşü hakimdir (Koçak vd. 2005:180).

Daha öncede ifade edildiği üzere, literatürde kaynak avantajı teorisi ve pazar yönlülükle ilgili çalışmalar vardır ve bu çalışmalar hem kavramsal hem de uygulamalı çalışmalardır. Bunlardan Koçak vd. (2005) çalışmalarında, kaynak temelli bakış açısına ilişkin literatürü incelemişler ve pazarlama kabiliyetleri ile ilişkisini araştırmışladır. Bu çalışmanın içeriğinde kaynak temelli yaklaşım ile pazar odaklılı̆̆ın rekabet avantajı oluşturmadaki önemine değinilmiş ve "daha etkin bir rekabet avantajının bu iki yaklaşımın sentezi ile elde edilebileceği” (Koçak vd. 2005:180) vurgulanmıştır. Güleş ve Özilhan (2010) çalışmalarında kaynak temelli teori bağlamında üretim ve pazarlama stratejilerinin işletme performansına etkisini araştırmışlardır. İşletmelerin sahip olduğu kaynakların üretim ve pazarlama performansına ve dolayısıyla da işletme performansına olumlu etki ettiğini (Gülçe ve Özilhan, 2010:488) bulmuşlardır. Bicen ve Hunt (2012) çalışmalarında, yeni ürün geliştirmede kaynak avantajı teorisi ve pazar yönlülüğün işbirliğinin önemini kavramsal olarak ortaya koymuşladır. Doğanay ve Kırcova (2016) çalışmalarında, 
kaynak avantajı teorisini sürdürülebilir pazarlama bağlamında incelemişler ve işletmelerin rekabetçi ortamda faaliyetlerini yürütürken çevreye de duyarlı olmaları gerektiğini vurgulamışlardır. Topaloğlu, McDonald ve Hunt (2018) ise kâr amacı gütmeyen kuruluşlar üzerine yaptığı çalışmalarında kaynak avantajı teorisi bağlamında kuruluşların, yalnız karşılaştırmalı üstünlüğe sahip kaynaklarını iyi değerlendirdiği ve sürdürülebilir rekabet avantajını devam ettirdiği takdirde, sosyal değere ve üstün finansal performansa sahip olacağını vurgulayarak, konuyu desteklemişlerdir.

Literatürde pazar yönlülük ve özellikle de pazar yönlülüğün işletme performansı ile ilişkisini irdeleyen çalışmalar da vardır. Karahan ve Özçiftçi (2008) çalışmalarında işletmelerin pazar yönlülük kültürünü benimseme durumları ve izledikleri pazar yönlü stratejilerin performans üzerine etkilerini araştırmışlardır. Ayrıca Marangoz ve Aydın (2012) çalışmasında, KOBI'lerde pazar yönlülüğün firma performansı ile ilişkilerini araştırmış ve pazar yönlülüğün firma performansına olumlu etki ettiği sonucuna ulaşmışlardır. Durukan ve Hamşığlu (2015) çalışmalarında, işletmelerin rekabet avantajı elde etmede pazar yönlülük ve pazarlama yeteneklerinin ihracat performansı üzerindeki olası etkilerini araştırmışlardır. Araştırma sonuçlarına göre, pazar yönlülük ve pazarlama yetenekleri ile ihracat performansı arasında anlamlı ve pozitif bir ilişki bulmuşlardır. Chia Wu (2017)'nin çalışmasında işletmelerin üstün finansal performans elde edebilmeleri için gerekli maddi olmayan kaynaklarla birlikte sürdürülebilir rekabet avantajı elde etmeleri için pazar yönlülük ve bütünleşik pazarlama iletişiminin çapraz işlevsel entegrasyonun önemini vurgulayarak çeşitli önermelerde bulunmuşlardır. Hamşığlu (2018)'in çalışmasında ise pazar yönlülük ile örgütsel stratejilerin işletme performansı üzerindeki olası etkileri araştırılmış ve pazar yönlülüğün, örgütsel strateji ve işletme performansı üzerinde doğrudan ve pozitif etkisi olduğu sonucuna ulaşılmıştır.

Kısaca kaynak avantajı teorisinin temel unsurları ile pazar yönlülüğün temel unsurlarının birlikte kullanımı ve uygulanması işletmelerin sürdürülebilir rekabet avantajı sağlamada önemli bir role sahiptir. Kaynak avantajı teorisi ve pazar yönlülükle ilgili yukarıda açıklanan ilgili çalışmalardan da görüleceği üzere doğrudan bu iki kavramın işletmelerin sürdürülebilir rekabet avantajı sağlamadaki rolünü ve önemini vurgulayan ve irdeleyen çalışmalar çok sınırlıdır. Bu bağlamda bu çalışma önemlidir.

\section{SONUÇ VE ÖNERILER}

Günümüz yoğun rekabet koşulları içerisinde faaliyet gösteren işletmelerin, büyük bir hızla karmaşıklaşan müşteri istek ve taleplerini etkin bir şekilde değer katarak karşılayabilmesi, üstün konumda pazar payına ve sürdürülebilir rekabet avantajına sahip olabilmek için, rakiplerinden üstün kılabilecek faaliyetlere ve yetkinliklere sahip olması gerekmektedir.

$\mathrm{Bu}$ nedenle, böylesine yoğun rekabet ortamı içerisinde işletmelerin pazarlama stratejileri, rekabet avantajını ellerinde bulundurabilmeleri için büyük önem arz etmektedir. Tam da bu noktada son dönemde yoğun olarak ilgi gören bir konu olarak öne çıkan kaynak avantajı teorisi pazarlama bakış açısıyla, işletmelerin 
sürdürülebilir rekabet avantajı sağlaması için, hangi unsurları dikkate alması gerektiğini açıklamaya çalışmaktadır.

Bununla birlikte, işletmelerin strateji seçimine yardımcı olan, müşterilerin isteklerine karşılık veren, rakipleri karşısında en iyi stratejinin belirlenmesi, üstün finansal performansla birlikte sürdürülebilir rekabet avantajına sahip olunmasına öncülük eden pazar yönlülük yaklaşımı ise işletmelerin benzersiz ve taklit edilmesi zor bir kaynağı olarak ifade edilmektedir. İşletmelerin stratejik kararlarında pazar yönlü anlayışa sahip olmasının, yeni ürünlerin başarısını olumlu olarak etkilediği, bununla birlikte proaktif olarak yenilik yapma kapasitesini geliştirerek işletme içi kaynak ve yeteneklerini daha etkin değerlendirebileceği düşünülmektedir.

Firmalar, kaynak avantajı teorisinde belirtilen rekabetçi pazar konumuna ve üstün finansal performansa sahip olabilmek için, pazarın bazı bölümlerindeki müşterilerine üstün değer sunarak, rekabet avantajı sağlayan pazar konumunu sürdürülebilir bir şekilde elde tutmak istemektedir. Karşılaştırmalı avantaja sahip olmak için rekabet eden işletmeler hem pazar yönlü hem de kaynak yönlü ilerledikleri takdirde sürdürülebilir rekabet avantajına sahip olacak şekilde stratejileri uygulayarak, üstün finansal performansa sahip olmaktadırlar.

Literatürde kaynak avantajı teorisi ile ilgili yapılan çalışmalar (Topaloğlu, McDonald ve Hunt, 2018; Wang vd., 2018; Friske, 2018; Chia Wu, 2017; Doğanay ve Kurcova, 2016; Peranginangin, 2015; Hunt, 2012; Hunt, 2011; Yalçın, 2010; Wittmann, Hunt ve Arnett, 2009; Hunt ve Davis 2008; Hunt ve Madhavaram, 2006) işletmelerin rekabet avantajını farklı şekillerde inceleyen (sürdürülebilir pazarlama, kar amacı gütmeyen kuruluşlar, pazarlama stratejileri vb) çalışmalardır. Bahsedilen çalışmalarda hem kaynak avantajı teorisinin temelleri ifade edilmekte hem de kaynak avantajı teorisinin farklı konularda ve uygulamalarda işletmelerin performansları üzerine etkisi irdelenmektedir.

Bununla beraber, kaynak avantajı teorisi ile ilgili bugüne kadar yapılan çalışmalar 1şı̆̆ında işletmelerin sahip oldukları kaynakların, üretim ve pazarlama sürecinde sürdürülebilir rekabetçi üstünlük sağlayan pazar yönlü yetenekleriyle birlikte kombine edilmesi, işletmelerin sektörleri içerisindeki genel performansları üzerinde olumlu etki yarattığını söylemek mümkündür. Bu çalışma kaynak avantajı teorisi ile pazar yönlülük kavramlarının işletmelerin sürdürülebilir rekabet avantajı sağlamadaki rolünü ve önemini teorik bir bakış açısıyla irdeleyen ilk çalışmalardan biridir. Bu bağlamda konunun kısıtları ve gelecekteki araştırmalar ile ilgili olarak şu öneriler yapılabilir.

- Kaynak avantajı teorisinin gerçekleştirilecek yeni çalışmalarla, işletmelere sürdürülebilir rekabet avantajını ellerinde bulundurulmaları için yol gösterici olacağını belirtmek mümkündür. Bu bağlamda, kaynak avantajı teorisine yönelik Türkçe literatürde az sayıda uygulamalı çalışma olduğundan dolayı Türkçe yazına katkı sağlayacak uygulamalı çalışmalar yapılması önerilmektedir.

- Ayrıca gelecekteki çalışmalar imalat sektörü içerisinde bulunan işletmeler üzerinde gerçekleştirilebilir. İşletmelerin sayılarının ve ölçeklerinin farklı olması sebebiyle araştırma farklı sektörlerde faaliyet gösteren küçük ve orta 
boy işletmeleri (KOBİ) kapsayacak şekilde (işletmelerinin kaynak avantajı teorisi ve pazar yönlülük anlamında) karşılaştırmalar yapılması önerilmektedir.

- Bir diğer yandan, sürdürülebilir rekabet avantajı sağlanmasında kaynak avantajı teorisi ve pazar yönlülük ile ilgili araştırmaların, şehirler bazında bazı işletmelere uygulanması, genelleme yapılmasını engelleyebilmektedir. Daha genel sonuçlara ulaşabilmek adına ileride yapılacak olan çalışmaların farklı coğrafi bölgelerdeki KOBİ'lere ya da diğer ölçekteki işletmelere uygulanması önerilmektedir.

- Kaynak avantajı teorisi ve pazar yönlülük kavramlarının kâr amaçlı ve kar amaçsız örgütler bağlamında rekabet edebilirlikleri açısından değerlendirilmelerine yönelik çalışmalarında yapılması önerilmektedir.

\section{KAYNAKÇA}

Arnett, D. B., \& Hunt, S. D. (2002). Competitive Irrationality: The influence of Moral Philosophy. Business Ethics Quarterly, 12(3), 279-303.

Aydın Güler, D. (2005). A. Smith ve J. A. Schumpeter'in Dinamik Rekabet Teorileri. Hacettepe Üniversitesi Iktisadi ve İdari Bilimler Fakültesi. Dergisi, 23 (1), 1-15.

Ayyıldız Ünnü, N. A. (2009). Politik Pazarlamada Pazar Yönlülük ve Otantik Liderliğin Önemi, Ege Akademik Bakış Dergisi, 9(4), 1243-1273.

Bulut M., Eraslan, İ.H. \& Şahin, Ö. (2004). Elmas Modeli ile Ankara Bilişim Kümelenmesi Rekabet Analizi. 3. Ulusal Bilgi, Ekonomik ve Yönetim Kongresi, 25-26 Kasım.

Baker, W. E., \& Sinkula, J. M. (2005). Market Orientation and The New Product Paradox. Journal of Product Innovation Management, 22(6), 483-502.

Barney, J., (1991). Firm Resources and Sustained Competitive Advantage, Journal of Management, 17 (1), 99- 120.

Bicen, P. \& Hunt, S.D. (2012). Alliance Market Orientation, New product Development, and Resource Advantage Theory. Journal of Business \& Industrial Marketing, 27(7), 592-600.

Chetkovich, C., \& Frumkin, P. (2003). Balancing Margin and Mission: Nonprofit Competition in Charitable Versus Fee-Based Programs. Administration and Society, 35(5), 564-596.

Chia Wu, Y. (2017). Resource-Advantage Theory: A Foundation of Integrated Marketing Communication and Market Orientation to Achieve Superior Performance. Proceedings of The Association of Collegiate Marketing Educators, 55-62.

Collis, D.J (2006). Research Note: How Valuable Are Organizational Capabilities. Strategic Management Journal, 15, 143-150.

Corbin, J. J. (1999). A Study of Factors Influencing The Growth of Nonprofits in Social Services. Nonprofit and Voluntary Sector Quarterly, 28(3), 296-314.

Demir, Y., \& Demirel, E. T. (2011). Rekabet Avantaj1 Yaratmada Entelektüel Sermayenin Önemi. Is Güç Endüstri İlişkileri ve Insan Kaynakları Dergisi, 13(1), 81-104.

Deng, S., \& Dart, J. (1994). Measuring Market Orientation: A Multi-factor, Multi-item Approach, Journal of Marketing Management, 10, 725-742.

Doğanay, Ö., \& Kırçova, İ. (2016). Kaynak Avantaj Teorisi Perspektifinden Sürdürülebilir Pazarlama. Pazarlama ve Pazarlama Araştırmaları Dergisi, 9(17), 25-41.

Durukan, T., \& Hamşioğlu, B. A. (2015). Pazar Yönlülük, Pazarlama Yeteneklerinin Rekabet Avantaj1 Elde Etmede İhracat Performans1 Üzerine Etkileri: Ankara İli İhracat İşletmelerinde Bir Uygulama. JEBPIR, 1(2), 1-19.

Ekber, Ş., \& Ahmadov, F. (2017). Pazar Odaklılık Yaklaşımları: Bir Literatür İncelemesi. Uygulamalı Sosyal Bilimler Dergisi, 1(1), 33-44.

Eren, M. Ş., Tokgöz, E., Gül, H. \& Saylan, O. (2013). Pazar Odaklılığın Nitel Performans Üzerindeki Etkisinde Öğrenme Odaklılık ve Yenilikçiliğin Düzenleyici Etkisi. Dokuz Eylül Üniversitesi İktisadi ve İdari Bilimler Fakultesi Dergisi, 28(2), 1-39. 
Mehmet Marangoz \& Tuğçe Merve İnak Özberk / Sürdürülebilir Rekabet Avantajı Sağlamada Kaynak Avantajı Teorisi ve Pazar Yönlülük Yaklaşımı

Friske, W. M. \& Zachary, M. A. (2018). Regulation, New Venture Creation, and Resource-Advantage Theory: An Analysis of the U. S. Brewing Industry. Entrepreneurship Theory and Practice, $1-19$.

Güleş, H. K., \& Özilhan, D. (2010). Kaynak Temelli Teori Bağlamında Üretim ve Pazarlama Stratejilerinin İşletme Performansı Üzerine Etkisinin İncelenmesi. S.Ü. IIIBF Sosyal ve Ekonomik Araştırmalar Dergisi, 10(19), 477-490.

Grant, R. M. (1991). The Resource-Based Theory of Competitive Advantage: Implications for Strategy Formulation. California Management Review Spring, 114-134.

Güngör, M.Ö. (2016). Pazarlama Biliminde 29 İnsan 29 Kavram, Beta Basım Yayım, İstanbul.

Hamşıŏglu, B., \& Durukan, T. (2018). Pazar Tabanlı Yeteneklerin İşletme Performansı Üzerindeki Etkisi: Türkiye İmalat İşletmelerinde Bir Uygulama. Eskişehir Osmangazi Üniversitesi İIBF Dergisi, 13(2), 1-22.

Hamşığlu, A.B. (2018). Pazar Yönlülük ve Örgüt Stratejilerinin İşletme Performansı Üzerindeki Etkisi. International Journal of Disciplines Economics \& Administrative Sciences Studies, 4(9), 437-451.

Hooley, G., Broderick, A., \& Möller, K. (1998). Competitive Positioning and the Resource- Based View of the Firm. Journal of Strategic Marketing, 6(2), 97-115.

Hunt, S. D., \& Morgan, R. M. (1995). The Comparative Advantage Theory of Competition. Journal of Marketing, 59(2), 1-15.

Hunt, S. D., \& Morgan, R. M. (1996). The Resource-Advantage Theory of Competition: Dynamics, Path Dependencies, and Evolutionary Dimensions. The Journal of Marketing, 60(4), 107114.

Hunt, S. D. (2000). A General Theory of Competition: Too Eclectic or not Eclectic Enough? Too Incremental or not Incremental Enough? Too Neoclassical or not Neoclassical Enough? Journal of Macro Marketing, 20(1), 77-81.

Hunt, S. D., \& Lambe, C. J. (2000). Marketing's Contirbution to Business Strategy: Market Orientation, Relationship Marketing and Resource-Advantage. International Journal of Management Reviews, 2(1), 17-43.

Hunt, S. D. (2002). Marketing and A General Theory of Competition. Journal of Marketing Management, 18(1-2), 239-247.

Hunt, S. D., Arnett, D. B., \& Madhavaram, S. (2006). The Explanatory Foundations of Relationship Marketing Theory. Journal of Business Industrial Marketing Theory, 21 (2), 72-87.

Hunt, S. D., \& Madhavaram, S. (2006). Teaching Marketing Strategy: Using Resource- Advantage Theory as an Integrative Theoretical Foundation. Journal of Marketing Education, 28 (2), 93-105.

Hunt, S. D., \& Davis, D. F. (2008). Grounding Supply Chain Management in Resource-Advantage Theory. Journal of Supply Chain Management, 44(1), 10-21.

Hunt, S. D. (2011). Sustainable Marketing, Equity, and Economic Growth: A Resource Advantage, Economic Freedom Approach. Journal of the Academy of Marketing Science, 39(7), 7-20.

Hunt, S. D. (2011). Developing Successful Theories In Marketing: Insights From Resource Advantage Theory. Academy of Marketing Science Journal, 1(2), 72-84.

Hunt, S. D. (2012). Toward the Institutionalization of Marcromarketing: Sustainable Enterprise, Sustainable Marketing. Sustainable Development and the Sustainable Society, 406-408.

Hunt, S. D. (2015). Marketing Theory: Foundations, Controversy, Strategy, Resource Advantage Theory, Routledge, New York.

Hunt, S. D. (2018). Advancing Marketing Strategy in the Marketing Discipline and Beyond: From Promise, to Neglect, to Prominence, to Fragment, (to promise?). Journal of Marketing Management, 34(1-2), 16-51.

Kaplan, R. S. (2001). Strategic Performance Measurements and Management in Nonprofit Organizations. Nonprofit Management and Leadership, 11(3), 353-370.

Karahan, K. \& Özçiftçi V. (2008). Pazar Yönlülük: Aksaray İli Perakende Hizmet İşletmelerinde Bir Uygulama. Selçuk Üniversitesi Sosyal Bilimler Enstitüsü Dergisi, 11(3), 479-492. 
Kayabaşı, A. (2007). İşletmelerin Rekabet Gücünün Geliştirilmesinde Lojistik Faaliyetlerin Performansının Arttırılması: Üretim İşletmeleri Üzerine Bir Uygulama. Sosyal Bilimler Enstitüsü Işsetme Anabilim Dall, Yayınlanmış Doktora Tezi, Dokuz Eylül Üniversitesi.

Kaygın, E. (2012). Sürdürülebilir Bir Rekabet Avantajı Sağlamanın Yolu: İç Girişimcilik Anlayışı. Sosyal ve Beşeri Bilimler Dergisi, 4(1), 93-103.

Koçak, A., Özer, A., \& Gürel, E. (2005). Kaynak Temelli Yaklaşımda Pazarlama Kabiliyetinin Boyutları. H. Ü. İktisadi ve İdari Bilimler Fakültesi Dergisi, 23(1), 179-201.

Kohli, A. K., \& Jaworski, B. J. (1990). Market Orientation: The Construct, Research Propositions, and Managerial Implications. Journal of Marketing, 54(2), 1.

Langerak, F. (2001). Effects of Market Orientation on The Behaviors of Salespersons And Purchasers, Channel Relationships, and Performance of Manufacturers, International Journal of Research in Marketing, 18, 221-234.

Laverie, D. A., \& McDonald, R. E. (2007). Volunteer Dedication: Understanding The Role of Identity Importance on Participation Frequency. Journal of Macromarketing, 27(3), 274-288.

Marangoz, M. \& Aydın, A.E. (2012). KOBİ'lerde Pazar Yönlülük ve Performans İlişkisi, 8. KOBİler ve Verimlilik Kongresi. 27 - 28 Kas1m 2012, 141-151.

Mata, F.J., Fuerst, W.L., \& Barney, J. B. (1995). Information Technology and Sustained Competitive Advantage: A Resource- Based Analysis, MIS Quarterly, 19(4), 487-505.

McDonald, R. E., Weerawardena, J., Madhavaram, S., \& Sullivan Mort, G. (2015). From "Virtuous" to "Pragmatic" Pursuit of Social Mission: A Sustainability-Based Typology of Nonprofit Organizations and Corresponding Strategies. Management Research Review, 38(9), 970991.

Morgan, R. M., \& Hunt, S. D. (1999). Relationship-based competitive advantage: The role of Relationship Marketing in Marketing Strategy. Journal of Business Research, 46(3), 281290.

Narver, J. C., \& Slater, S. F. (1990). The Effect of a Market Orientation on Business Profitability. Journal of Marketing, 20-35.

Narver J.C. \& Slater, S.F. (1995). Market Orientation and Learning Organization, Journal of Marketing, 59 (3). 63-74.

Narver, J. C., Slater, S. F., \& MacLachlan, D. L. (2004). Responsive and Proactive Market Orientation and New Product Success. Journal of Product Innovation Management, 21(5), 334-347.

Nelson, P. (1970). Information and Consumer Behavior. Journal of Political Economy, 78 (2), 311329.

Özbağ Kaya, G., (2016). Rekabet Avantajı Yaratmada İki Temel Yaklaşım; Kaynak Tabanlı ve Endüstri Tabanlı Yönetim Modeli, Yeni Türkiye Dergisi, 88, 888- 899.

Peranginangin, J. (2015). A Conceptual Mapping Resource Advantage Theory, Competitive Advantage Theory, and Transient Competitive Advantage. Expert Journal of Business and Management, 3(2), 140-149

Porter, M.E., (1980). Competitive Strategy: Techniques for Analyzing Industries and Competitor, New York: The Free Press.

Porter, M.E. (1985). Competitive Advantage: Creating and Sustaining Superior Performance, The Free Press, New York.

Porter, M.E. (2008). The Five Competitive Forces That Shape Strategy. Harvard Business Review, 3 (2), 24-41.

Senge, P.M., (1990). The Fifth Discipline: The Art and Practice of the Learning Organization, New York, NY: Double Day/ Currency Press.

Seviçin, A. (2009). Sürdürülebilir Rekabet Üstünlüğü Kavramı Üzerine Bir İnceleme. ZKÜ Sosyal Bilimler Dergisi, 5(10), 171-185.

Slater S.F. \& Narver, J.C. (1994). Market Orientation Value, And Superior Performance, Business Horizons, 37 (2), 3-18.

Şahin, B. (2018). Pazar Odaklılık Bileşenlerinin Firma Performansına Etkileri: Ankara'da Faaliyet Gösteren Startuplar Üzerine Bir Uygulama. Business Management Studies: An International Journal, 6(2), 675-693. 
Taşkın, E. Kayabaşı, A., \& Kiracı, H. (2011). Rekabetçi Yöntemlerin İşletme Performansı Üzerine Etkisi: İnegöl'de Faaliyet Gösteren ve İhracat Yapan İşletmeler Üzerine Bir Alan Araştırması. Pazarlama ve Pazarlama Araştırmaları Dergisi, 8, 105-122.

Teece, D.J., Pisano, G. \& Shuen, A.,(1997). Dynamic Capabilities and Strategic Management, Strategic Management Journal, 18, 509- 533.

Tek Ö.B. (2004). Pazarlama İyi İnsan Olmanın Bilimidir, Pazarlama Dünyası Dergisi, 12, (67). 5-22. Topaloğlu, Ö. McDonald, R. D., \& Hunt, S. D. (2018). The Theoretical Foundations of Nonprofit Competition: A Resource-Advantage Theory Approach. Journal of Nonprofit \& Public Sector Marketing, 30(3), 229-250.

Yalçın, B. (2010). Kaynak Avantajı Kuramı Üzerine Kavramsal Bir Bakış. Işsletme ve Ekonomi Araştırmaları Dergisi, 1 (2), 63-71.

Wang, Y. J., Capon, N., Wang, V. L., \& Guo, C. (2018). Building Industrial Brand Equity on Resource Advantage. Industrial Marketing Management, 72, 416.

Wittmann, M. C., Hunt, S. D., \& Arnett. (2009). Explaining Alliance Success:Competences, Resources, Relational Factors, and Resource-Advantage Theory. Industrial Marketing Management, 38 (7), 4-16.

\section{SUMMARY}

In a global competitive environment, enterprises aiming to provide a sustainable competitive advantage seek to exist in the market with accurate marketing strategies by identifying their strengths-weaknesses and opportunities within the sector in the direction of their basic capabilities and resources.

In order to have sustainable competitive advantage, it is possible to see a source based approach and a market oriented approach in marketing strategies that can be developed from past to present. According to the source-based approach, the idea of providing competitive advantage depends on the resources and capabilities of the enterprise. However, the market-oriented approach is; In order to provide sustainable competitive advantage, it is stated that the existing and potential customer needs in the market and the data obtained are shared within all business functions and the needs are met more effectively and efficiently than the competitors. It is possible to say that the synthesis of both approaches will have a very important effect in terms of enterprises gaining a competitive competitive advantage.

Today, businesses are developing various strategies to keep sustainable competitive advantage in the current competitive environment. Hunt and Morgan (1995) first introduced the resource advantage theory based on the resources and competencies of the enterprises that examined the competitive advantage. The basic proposition of the theory is that it provides superior financial performance by providing a competitive advantage to enterprises that cannot be imitated, valuable and rare. In addition, according to the theory of resource advantage, market orientation is expressed as a source of the enterprises because it provides proactive customer satisfaction information by producing an appropriate product according to the preferences of the market segments. The aim of the study is to evaluate the importance of resource advantage theory and market orientation in enterprises to achieve sustainable competitive advantage and to make suggestions to the literature by making suggestions. As a result, the importance of supply, consumer knowledge, human motivation, business purpose and knowledge, resources, the 
role of management, competitive dynamics, and the importance of providing sustainable competitive advantage in market direction are emphasized.

As a result, companies operating in today's hyper-competition conditions need to have activities and competencies that can exceed their competitors in order to be able to meet customer demands and demands with value at a great speed and to have a superior market share and sustainable competitive advantage. Therefore, the marketing strategies of the enterprises in such an intense competition environment are of great importance in order to keep their competitive advantage. At this point, it is tried to explain which factors should be taken into consideration by the marketing advantage perspective in order to provide sustainable competitive advantage. On the other hand, the market-oriented approach, which helps enterprises to choose strategies, respond to customers' requests, determine the best strategy against their competitors, and have a sustainable competitive advantage with superior financial performance, is expressed as a unique and imitation source of enterprises. It is thought that having a market-oriented understanding of the strategic decisions of the enterprises positively affects the success of the new products, and that they can proactively improve their capacity to innovate and evaluate their in-house resources and capabilities more effectively.

In order to have a competitive market position and superior financial performance in terms of resource advantage theory, firms want to maintain a sustainable market position by providing superior value to their customers in some parts of the market. In order to have a comparative advantage, competing companies have superior financial performance by implementing strategies that will have a sustainable competitive advantage if they progress both in terms of market and source. In the light of the studies on resource advantage theory, it is possible to say that the resources of the enterprises have a positive effect on the overall performance of the enterprises within the sectors, combined with the market-oriented capabilities that provide sustainable competitive advantage in the production and marketing process. This study examines the role and importance of resource advantage theory and market orientation concepts in providing sustainable competitive advantage of enterprises. 